\title{
Optimisation of a gas chromatography-mass spectrometry method for the simultaneous determination of tetrahydrocannabinol and its metabolites in rat urine
}

\author{
Nino Fuchs ${ }^{1 *}$, Alena Miljanić2*, Anja Katić3 ${ }^{3}$, Nataša Brajenović3 ${ }^{3}$, Vedran Micek ${ }^{3}$, Radovan Fuchs ${ }^{3}$, \\ and Irena Brčić Karačonji ${ }^{3}$ \\ ${ }^{1}$ University Hospital Centre Zagreb, Croatia \\ ${ }^{2}$ Department of Biotechnology, University of Rijeka, Croatia \\ ${ }^{3}$ Institute for Medical Research and Occupational Health, Zagreb, Croatia
}

[Received in October 2019; Similarity Check in October 2019; Accepted in December 2019]

In order to evaluate the effect of irinotecan (IRI) on urinary elimination of delta-9-tetrahydrocannabinol (THC) in a rat experimental model, we developed an analytical method for the determination of the mass concentration of THC and its metabolites [11-hydroxy-delta-9-tetrahydrocannabinol (THC-OH) and 11-nor-9-carboxy-delta-9-tetrahydrocannabinol (THC-COOH)] in the urine of rats treated only with THC and treated simultaneously with THC and irinotecan. For this purpose, hydrolysis and solid phase extraction conditions of the investigated analytes were optimised and a gas chromatography-mass spectrometry (GC-MS) method was developed to determine all three analytes in rat urine. The most effective hydrolysis method for THC, THC-OH, and THC-COOH conjugates was so-called tandem hydrolysis by the $\beta$-glucuronidase enzyme from Escherichia coli at $50^{\circ} \mathrm{C}$ for 2 hours and followed by alkaline hydrolysis. The proposed method was then applied for determining concentrations of analytes in 24-hour rat urine. THC was not detected in either sample, THC-OH was detected in $50 \%$ of samples, and THC-COOH in all of the samples. Enhanced urinary THC-COOH excretion was noted in rats administered combined treatment compared to single THC treatment. The method described herein was suitable for determining the mass concentration of THC metabolites in the rat urine due to its sensitivity (detection limits: $0.8-1.0 \mu \mathrm{g} / \mathrm{L})$, accuracy $(>96 \%)$, and precision $(\mathrm{RSD}<6 \%$ ).

KEY WORDS: analytical validation; cannabis; GC-MS; hydrolysis; irinotecan

Delta-9-tetrahydrocannabinol (THC) is the main psychoactive substance in the plant Cannabis sativa. Lately, interest in the therapeutic effects of cannabinoids and the development of cannabinoid-derived medicine has risen, among others, for the purpose of alleviating symptoms such as diarrhoea, abdominal pain, nausea caused by chemotherapy, vomiting, etc. (1). Most of the aforementioned symptoms appear during therapy with the antitumor drug irinotecan (7-ethyl-10-[4-(1-piperidino)-1-piperidino] carbonyloxycamptothecin, IRI, CPT-11) whose primary purpose was chemotherapy in metastatic colorectal cancer, but was also proven to be effective in treating lung cancer, ovarian cancer, leukaemia, and malignant glioma (2).

Although there are several conventional therapies that could relieve the undesired effects of antitumor drugs, we are faced with the growing use of cannabinoid-containing oral preparations administered for this purpose. Unlike approved and registered products that contain a standardised and defined dose of THC, illegal products with untested compositions may contain a high THC concentration. This

\footnotetext{
Corresponding author: Irena Brčić Karačonji, $\mathrm{PhD}$, Institute for Medical Research and Occupational Health, Ksaverska cesta 2, 10001 Zagreb, Croatia E-mail:ibrcic@imi.hr
}

*The authors contributed to this work equally. exposes patients to increased risks of harmful effects, as well as to potential intoxication. Apart from insufficient data on the therapeutic efficacy of such products, there is also concern regarding the potentially negative effects that result from the pharmacokinetic and pharmacodynamic interactions of cannabis' main components with standard drugs (3). The quantification of cannabinoids in urine is necessary in pharmacokinetics studies in order to evaluate the potential impact of the chemotherapeutics (e.g. IRI) on THC metabolism.

Due to the fast metabolism of cannabinoids, concentrations of THC metabolites are much higher in urine than in blood, so urine is considered the biological sample of choice for the identification and quantification of cannabinoids (4). Furthermore, urine as a biological material is relatively easy to obtain (5).

Cannabinoids are rapidly and extensively metabolised by hepatic enzymes. The hydroxylation of THC yields the psychoactive component 11-hydroxy-delta-9tetrahydrocannabinol (THC-OH), whereas further oxidation leads to the inactive 11-nor-9-carboxy-delta-9tetrahydrocannabinol (THC-COOH) excreted by urine mostly as a conjugate of glucuronic acid (6). Glucuronidation 
is catalysed by uridine diphosphate-glucuronyltransferases (UGTs) (7).

The unambiguous identification of cannabinoids and metabolites in urine was carried out by a gas chromatograph $(4,8,9)$ or a high performance liquid chromatograph (1013) coupled with a mass spectrometer as a detector. High performance liquid chromatography-mass spectrometry (HPLC-MS) enables direct conjugate detection, while the widely used gas chromatography-mass spectrometry (GCMS) requires hydrolysis of conjugates before extraction and analysis to quantify a total concentration (free and conjugated fraction) of the measured analytes. Considering that cannabinoids and their metabolites are present in urine mainly in the form of conjugates, it is necessary to hydrolyse these compounds. Enzymatic hydrolysis using $\beta$-glucuronidases is effective for the cleavage of the glucuronide bond in THC and THC-OH glucuronides, while alkaline hydrolysis is more effective for splitting THC$\mathrm{COOH}$ glucuronides (14). In order to separate the desired analytes from the complex sample matrix before instrumental analysis, organic solvent extraction ( $n$-hexane, ether, ethyl acetate, etc.) $(10,15)$ or solid phase extraction (SPE) $(4,8$, $9,12,13)$ were employed.

Although rats have often been used as an experimental model for understanding the metabolism of drugs (16-20), to the best of the authors' knowledge, urinary THC and metabolite detection following oral application of THC has not yet been studied. In the existing literature we have found optimised and validated chromatographic methods only for the determination of concentrations of cannabinoids and metabolites in human urine. Considering that rat urine differs from human urine in composition, a reliable method for the detection and quantification of THC and its metabolites in rat urine is required. Therefore, this study optimised the hydrolysis and extraction conditions for THC and its metabolites (THC-OH and $\mathrm{THC}-\mathrm{COOH}$ ) and developed and validated a GC-MS method for the simultaneous determination of the mass concentration of all three analytes in rat urine. The proposed method was applied to determine the THC, THC-OH, and THC-COOH concentration in 24-hour urine of rats treated only with $\mathrm{THC}$ or THC and IRI simultaneously.

\section{MATERIALS AND METHODS}

\section{Chemicals and reagents}

THC (Dronabinol; CAS-No. 1972-08-3) was obtained from THC Pharm GmbH (Frankfurt, Germany). Before administration, THC was dissolved in sesame oil (Bio Primo, Ulm, Germany). IRI (CAS-No. 100286-90-6) was provided as the hydrochloride trihydrate salt by LC Laboratories (Woburn, MA, USA). It was diluted in sterile $0.9 \%$ sodium chloride solution (Croatian Institute for Transfusion Medicine, Zagreb, Croatia).
Analytical standards of THC (1 g/L), THC-OH $(0.1 \mathrm{~g} / \mathrm{L}), \mathrm{THC}-\mathrm{COOH}(1 \mathrm{~g} / \mathrm{L})$, and THC-COOH$-d_{3}(1 \mathrm{~g} / \mathrm{L}$; internal standard) were purchased from Lipomed (Vienna, Austria). Intermediate stock solutions $(1000 \mu \mathrm{g} / \mathrm{L})$ were prepared by dilution with methanol and were stored at $-20{ }^{\circ} \mathrm{C}$. Methanol, dichloromethane, $n$-hexane, and ethyl acetate (HPLC grade) were purchased from Merck (Darmstadt, Germany), while glacial acetic acid (99.5\%), isopropyl alcohol, ammonium hydroxide, potassium phosphate monobasic, and potassium hydroxide were analytical-grade-purity products of Kemika (Zagreb, Croatia). N,O-bis(trimethylsilyl)trifluoroacetamide (BSTFA) with $1 \%$ trimethylchlorosilane (TMCS) was obtained from Restek (Bellefonte, PA, USA).

$\beta$-glucuronidases [from Escherichia coli (type IX-A, lyophilized powder, 1,000,000-5,000,000 units/g protein) and from Helix pomatia (type $\mathrm{H}-2$, aqueous solution, $\geq 85,000$ units $/ \mathrm{mL}$ )] were purchased from Sigma (St. Louis, MO, USA). A working solution of $\beta$-glucuronidase from E. coli was prepared by dissolving the enzyme in $0.1 \mathrm{~mol} / \mathrm{L}$ phosphate buffer $\mathrm{pH} 6.8$.

Ultra-pure water was obtained from a Milli-Q water purification system (Millipore, Bedford, MA, USA).

\section{Animals}

For the purpose of this study, adult male three-month old Wistar HsdBrlHan rats were supplied by the animal facility of the Institute for Medical Research and Occupational Health, Zagreb (Croatia). Animals were kept in standard clear polycarbonate cages (Ehret, Tulln, Austria) under pathogen-free and steady-state microenvironmental conditions, $12 \mathrm{~h}$ light/dark cycle, room temperature 20$22{ }^{\circ} \mathrm{C}$ and humidity $40-60 \%$, with ad libitum access to standard Good Laboratory Practice (GLP) certified food (Complete feed for mice and rats 4RF21, Mucedola, Italy) and tap water. Appropriate enrichment was provided in animal cages. The research procedures were carried out in compliance with international standards and the national law on the protection of animal welfare. The study was approved by the Ethics Committee of the Institute for Medical Research and Occupational Health, Zagreb, Croatia (approval number: 100-21/16-16, 30 June 2016).

\section{Experimental design}

Adult male rats with an initial body weight of $235 \mathrm{~g}$ to $249 \mathrm{~g}$ were randomly assigned to three groups, each comprising 5 animals. Rats were placed in metabolic cages for 24 hours for urine sample collection.

The THC group received a single dose of $7 \mathrm{mg}$ of THC/ $\mathrm{kg}$ body weight (bw) per os (p.o.). The IRI+THC group received IRI intraperitoneally (i.p.) via a single dose of $100 \mathrm{mg} / \mathrm{kg}$ bw and immediately afterwards $7 \mathrm{mg} / \mathrm{kg}$ of THC p.o. The control group was treated with sesame oil p.o. and kept in the same conditions. For the optimisation of the 
hydrolysis and extraction procedures, the THC group $(\mathrm{N}=5)$ received a single dose of $20 \mathrm{mg} \mathrm{THC} / \mathrm{kg}$ bw.

The urine samples were collected into $10-\mathrm{mL}$ polypropylene tubes over 24 hours from the moment of applying the tested substances. The samples from each rat were pooled and stored at $-20{ }^{\circ} \mathrm{C}$ until analysis.

\section{Optimised hydrolysis and solid phase extraction}

The urine samples of rats $(3 \mathrm{~mL})$ treated with $\mathrm{THC}$ or the THC and IRI combination were mixed with $6 \mathrm{~mL}$ of $0.1 \mathrm{~mol} / \mathrm{L}$ phosphate buffer $(\mathrm{pH} 6.8$ ) with the addition of $60 \mu \mathrm{L}$ of internal standard at concentrations of $1000 \mu \mathrm{g} / \mathrm{L}$ and $300 \mu \mathrm{L}$ of solution of $\beta$-glucuronidase from $E$. coli $(25,000 \mathrm{U} / \mathrm{mL})$. To create a calibration curve within the range of 3-100 $\mu \mathrm{g} / \mathrm{L}$, the urine of rats from the control group (negative for the tested analytes) was spiked with appropriate aliquots of analytical standards (THC, THC$\mathrm{OH}, \mathrm{THC}-\mathrm{COOH}$, and THC-COOH$\left.-d_{3}\right)$. The mass concentration of the internal standard was $20 \mu \mathrm{g} / \mathrm{L}$ in all of the samples. Samples were vortex mixed and the $\mathrm{pH}$ of the samples was confirmed to be 6-7. Enzymatic hydrolysis of samples was performed at $50{ }^{\circ} \mathrm{C}$ for 2 hours. After the samples were cooled, $300 \mu \mathrm{L}$ of $10 \mathrm{~mol} / \mathrm{L} \mathrm{KOH}$ was added, the samples were vortex mixed and chemical hydrolysis was carried out at $60{ }^{\circ} \mathrm{C}$ for $15 \mathrm{~min}$. After cooling, $165 \mu \mathrm{L}$ of glacial acetic acid and $2 \mathrm{~mL}$ of $0.1 \mathrm{~mol} / \mathrm{L}$ sodium acetate in $5 \%$ methanol ( $\mathrm{pH} 7.0$ ) were added to the samples. The measured $\mathrm{pH}$ values had to be within 4.5-6.5. The samples were centrifuged at $1400 \mathrm{~g}$ for $15 \mathrm{~min}$ and a supernatant was used for further procedures.

The extraction procedure was adjusted according to a previously optimised method for determining the mass concentration of THC-COOH in human urine (21). Bond Elut Certify II (Agilent Technologies, USA) columns were used for the solid phase extraction (SPE) of cannabinoids and metabolites from the urine samples. SPE columns were conditioned with $2 \mathrm{~mL}$ of methanol and $2 \mathrm{~mL}$ of $0.1 \mathrm{~mol} / \mathrm{L}$ sodium acetate in $5 \%$ methanol (pH 7.0). The sample was passed through a column and the column was then washed with $2 \mathrm{~mL}$ of methanol and water $(1: 1, \mathrm{v} / \mathrm{v})$ mixture. After drying the column for 2 min using vacuum, the analytes were eluted with $2 \mathrm{~mL}$ mixture of $n$-hexane:ethyl acetate: glacial acetic acid $(75: 25: 1, \mathrm{v} / \mathrm{v} / \mathrm{v})$.

The eluents were collected in glass tubes and evaporated to dryness under a stream of nitrogen at room temperature. The dry residue was mixed with $0.5 \mathrm{~mL}$ of toluene and evaporated in the same manner. Then, $50 \mu \mathrm{L}$ of BSTFA + $1 \%$ TMCS were added to the residue and the sample was capped, shaken, and derivatised for $15 \mathrm{~min}$ at $90^{\circ} \mathrm{C}$.

To optimise the hydrolysis and extraction conditions, we used urine from rats that orally received a single dose of THC (20 mg/kg bw) and had a measurable level of all three analytes in their urine. The hydrolysis efficiency was tested by using $\beta$-glucuronidase ( $5000 \mathrm{U} / \mathrm{mL}$ urine) originating from $E$. coli and $H$. pomatia using the following hydrolysis conditions: 1) $37{ }^{\circ} \mathrm{C}$ for 16 hours and 2) $50{ }^{\circ} \mathrm{C}$ for 2 hours. Afterwards, the obtained results were compared with a) chemical hydrolysis $(300 \mu \mathrm{L}$ of $10 \mathrm{~mol} / \mathrm{L} \mathrm{KOH}$, $60{ }^{\circ} \mathrm{C}$ for $15 \mathrm{~min}$ ) and b) tandem hydrolysis [chemical hydrolysis following hydrolysis by $\beta$-glucuronidase from E. coli (5000 U/mL urine), at $50{ }^{\circ} \mathrm{C}$ for 2 hours]. Also, to evaluate hydrolysis and extraction efficiency we tested the volume (3 and $6 \mathrm{~mL}$ ) of $0.1 \mathrm{~mol} / \mathrm{L}$ phosphate buffer $(\mathrm{pH}$ 6.8) which was added before hydrolysis, activity of $\beta$-glucuronidase from E. coli (5000 and $7000 \mathrm{U} / \mathrm{mL}$ ), which is sufficient to complete hydrolysis, and the effect of centrifugation (room temperature, $15 \mathrm{~min}, 1400 \mathrm{~g}$ ) on extraction.

\section{GC-MS analysis}

The analyses were carried out using a Trace 1300 gas chromatograph (Thermo Scientific, Milan, Italy) coupled to a ITQ 700 ion trap mass spectrometer (Thermo Scientific, Austin, TX, USA). The analytes were separated on a TG$5 \mathrm{MS}$ capillary column $(30 \mathrm{~m} \times 0.25 \mathrm{~mm}$ ID, $0.25 \mu \mathrm{m}$ film thickness, Thermo Scientific, Runcorn, UK). Helium was used as the carrier gas at a flow rate of $1 \mathrm{~mL} / \mathrm{min}$. Samples $(1 \mu \mathrm{L})$ were injected in the programmable temperature vaporizing (PTV) injector which temperature was held at $40{ }^{\circ} \mathrm{C}$ for $0.1 \mathrm{~min}$ and then increased to $280^{\circ} \mathrm{C}$ at $3{ }^{\circ} \mathrm{C} / \mathrm{s}$. The initial oven temperature was set at $50{ }^{\circ} \mathrm{C}$ for $1 \mathrm{~min}$, then increased to $250{ }^{\circ} \mathrm{C}$ at $50{ }^{\circ} \mathrm{C} / \mathrm{min}$, held for $1 \mathrm{~min}$, increased to $280{ }^{\circ} \mathrm{C}$ at $5{ }^{\circ} \mathrm{C} / \mathrm{min}$, and held for $1 \mathrm{~min}$. The transfer line temperature was set at $280{ }^{\circ} \mathrm{C}$. The ion source temperature was set at $200{ }^{\circ} \mathrm{C}$. The MS detector operated in electron impact ionisation mode. Three ions were monitored for each trimethylsilyl (TMS) derivative: THCTMS: $m / z \underline{371}$, 386, 303; THC-OH-2TMS: $m / z \underline{371}, 474$, 459; THC-COOH-2TMS: $m / z$ 371, 488, 473, and THCCOOH- $d_{3}$-2TMS: $m / z \underline{374}, 491,476$. The underlined ions were used for quantitation.

Analytes were identified by a comparison of the retention time of each tested analyte with the retention time of the analytical standards followed by a comparison between the obtained mass spectrum of each tested analyte and the mass spectrum from our own database and NIST13 mass spectra database. An internal standard method was used to quantitatively determine the analytes.

\section{Analytical validation of the GC-MS method}

The calibration curve was prepared using the final experimental parameters in the concentration range of 3-100 $\mu \mathrm{g} / \mathrm{L}$. The limit of detection (LOD) was calculated using a signal-to noise ratio of 3 . Precision and accuracy were evaluated by analysing the blank urine samples spiked with two different concentrations of THC, THC-OH, and THC-COOH (10 and $40 \mu \mathrm{g} / \mathrm{L})$ in six replicates. Accuracy was estimated by comparing the analyte concentration calculated from the calibration curve using the internal 
standard method with the theoretical value. Precision was expressed as relative standard deviation (RSD).

\section{Statistical analysis}

The statistical analysis of the results was carried out using the Dell ${ }^{\text {TM }}$ Statistica ${ }^{\text {TM }} 13.2$ software (StatSoft, Tulsa, OK, USA). The normality of distribution for numerical data was tested by Shapiro-Wilk's test. Due to an asymmetrical distribution of the measured parameters, results within groups were expressed as median with ranges, while statistical significance between the groups was confirmed by Mann-Whitney U-test. In cases when the concentrations were lower than the limit of detection, values $0.5 \mathrm{x}$ LOD were used for statistical analysis. The level of statistical significance was set at $\mathrm{p}<0.05$.

\section{RESULTS}

The development of the analytical procedure for the determination of THC and metabolites in rat urine included the optimisation of hydrolysis and extraction conditions, choosing appropriate chromatographic conditions that enable the efficient separation of selected analytes, determining accuracy and precision as well as the linearity and sensitivity of the detector's response. The largest peak area for the target ion of a particular analyte corresponded to the most efficient hydrolysis and extraction. All of the analyses were conducted in triplicate.

In the first experiment, the efficiency of two enzymes of different origin (from E. coli and H. pomatia) and different conditions: 1) $37^{\circ} \mathrm{C}$ for 16 hours and 2) $50{ }^{\circ} \mathrm{C}$ for 2 hours) for hydrolysis of conjugates of THC and metabolites in rat urine were tested. Hydrolysis using enzyme from $H$. pomatia did not enable the detection of THC, while all three analytes were detected when hydrolysis with enzyme from $E$. coli was performed using both hydrolysis conditions. There were no differences in the hydrolysis efficiency of THC and THC-OH conjugates in both of the applied conditions, while the efficiency of hydrolysis of THC-COOH conjugate was $45 \%$ greater at the higher temperature over the shorter hydrolysis time. With this in mind, for further hydrolysis experiments, the enzyme from $E$. coli was chosen with hydrolysis conditions at $50{ }^{\circ} \mathrm{C}$ during 2 hours. For THC-COOH-glucuronide hydrolysis, alkaline hydrolysis with $\mathrm{KOH}$ at $60{ }^{\circ} \mathrm{C}$ for 15 minutes was the most efficient. Combined (tandem) hydrolysis (enzymatic followed by alkaline) resulted in the most effective hydrolysis for all three conjugates (Figure 1).

In the following experiment, the effect of the amount of $\beta$-glucuronidase from $E$. coli $(5000$ and $7000 \mathrm{U} / \mathrm{mL}$ ) on the hydrolysis degree of the conjugates was tested. Considering that the hydrolysis was equally effective using both amounts of enzyme, the smaller quantity of enzyme $(5000 \mathrm{U} / \mathrm{mL})$ was used in further experiments.

A volume of $0.1 \mathrm{~mol} / \mathrm{L}$ phosphate buffer $(\mathrm{pH} 6.8 ; 3$; and $6 \mathrm{~mL}$ ) added to the urine sample before enzyme hydrolysis was also tested. The twice lower chromatogram baseline noise and the $20 \%$ larger surface of target peaks were achieved by using a more diluted sample ( $6 \mathrm{~mL}$ of buffer). An additional decrease of the chromatogram baseline noise ( $25 \%$ ) was achieved by centrifugation ( $15 \mathrm{~min}, 1400 \mathrm{~g}$ ) of the sample before adding it to the SPE column.

The proposed GC-MS conditions enabled the efficient separation of all of the tested analytes without interferences. IRI treatment did not influence the quality of the obtained

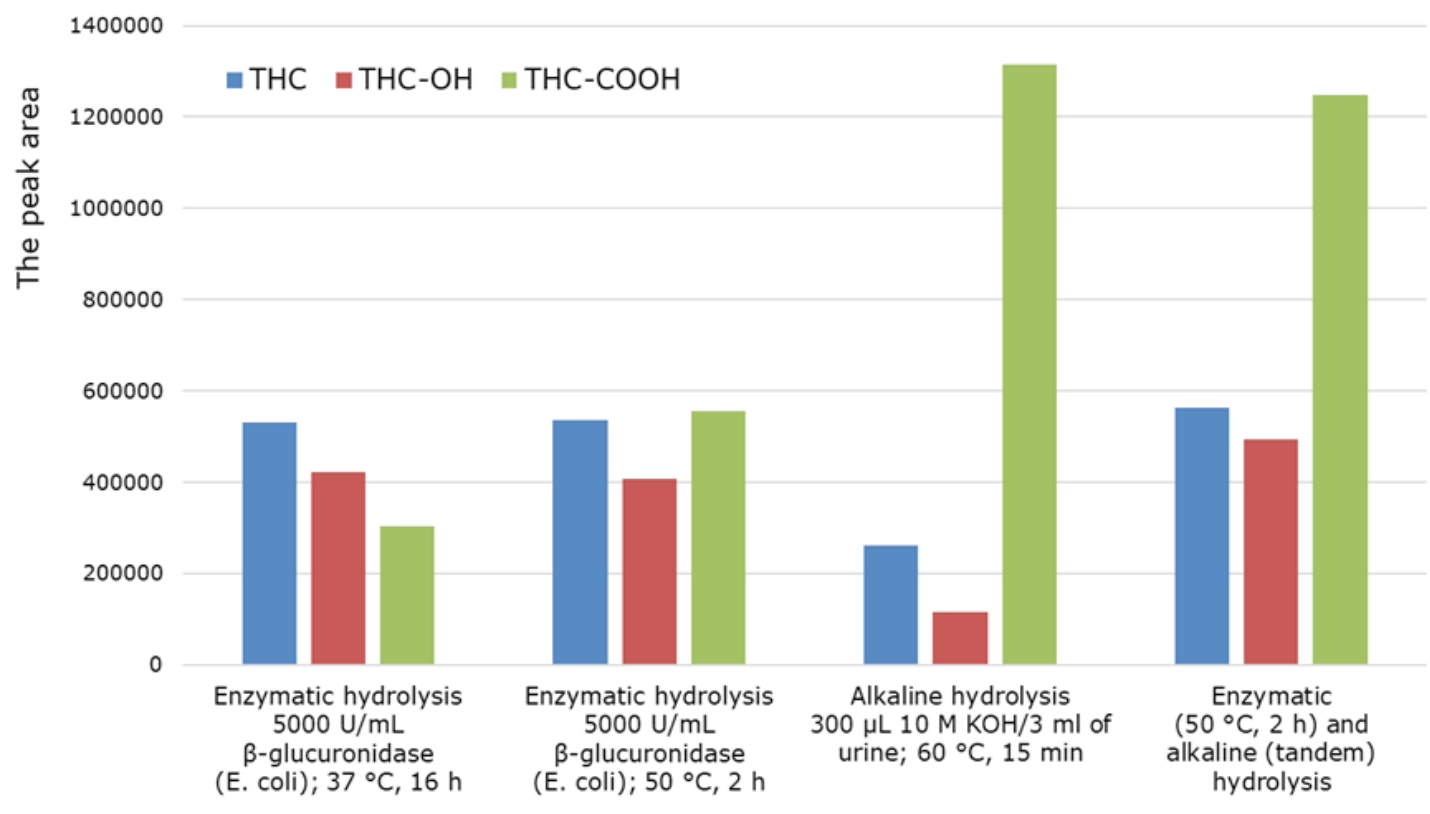

Figure 1 Comparison of different types of hydrolysis for cleavage of conjugates THC, THC-OH, and THC-COOH from 24-hour rat urine (pooled sample of five rats that received a single dose of $20 \mathrm{mg}$ of THC/kg bw orally) 
chromatograms. In order to avoid the appearance of additional peaks at higher column temperatures due to the impurities present in the complex sample matrix, after programmed heating to $280{ }^{\circ} \mathrm{C}$, the column remained at that temperature for an additional $0.5 \mathrm{~min}$.

Regressions were calculated for each of the calibration curves (THC, THC-OH, and THC-COOH, 3-100 $\mu \mathrm{g} / \mathrm{L}$ ) and they all showed good linearity with coefficients of determination $\left(\mathrm{R}^{2}\right)>0.9986, \mathrm{p}<0.01$. Table 1 shows the results of the analytical validation of the method for determining the mass concentration of cannabinoids and metabolites in rat urine. The limits of detection were within the range of $0.8-1.0 \mu \mathrm{g} / \mathrm{L}$, whereas accuracy exceeded $96 \%$ for both of the tested concentration levels. Precision, expressed as relative standard deviation (RSD), was $<6 \%$.

The suggested validated method was used to analyse 10 samples of 24-hour rat urine, five of which were treated with a single dose of THC ( $7 \mathrm{mg} / \mathrm{kg})$, while another five were treated with a single dose of THC $(7 \mathrm{mg} / \mathrm{kg})$ and IRI $(100 \mathrm{mg} / \mathrm{kg})$. The cannabinoid and metabolite concentrations in the 24-hour rat urine from the aforementioned two groups are shown in Table 2. THC was not detected in any of the samples, THC-OH was detected in $50 \%$ of samples, while THC-COOH was found in all of the samples. A statistically significantly higher mass concentration of the THC-COOH in urine was found in the THC+IRI group compared to the THC group.

\section{DISCUSSION}

Urine is the most frequently used biological sample for the analysis of metabolites, as it is easily available and contains larger quantities of metabolites than other body fluids (6). The metabolic profile of human and rat urine is quite different. Rat urine is richer in amino acids and is therefore thicker, more viscous, and less transparent (22). Considering the differences in the composition of human and rat urine, the complexity of the sample matrix, and differences in metabolic rate (rats metabolise THC more quickly due to the larger amount of enzymes from cytochrome system P450 per gram of body mass) (23), it was necessary to optimise and validate a GC-MS procedure for determining the $\mathrm{THC}$ and metabolite concentration in rat urine. To the best of our knowledge, the relevant literature does not contain a single mention of a validated method involving GC-MS used for the qualitative and quantitative determination of the aforementioned analytes in rat urine.

In the first experiment, we optimised the conditions of glucuronide hydrolysis, as during THC metabolism, THC and metabolite conjugation with glucuronic acid occurs and glucuronides are formed (9). Having in mind the polarity and size of a metabolite bound in the form of a glucuronide, it is not possible to analyse them using gas chromatography. For that reason, it is necessary to separate the analyte from the glucuronic acid by hydrolysis process. The enzyme $\beta$-glucuronidase isolated from $E$. coli bacteria showed better hydrolytic activity than the same enzyme isolated from the $H$. pomatia snale. The dependence of $\beta$-glucuronidase activity on the source of the enzyme is in accordance with literature sources that point to a weak hydrolytic activity of enzymes from $H$. pomatia towards THC and THC-COOH glucuronides (15). We monitored the efficiency of enzymatic hydrolysis by $\beta$-glucuronidase from $E$. coli over two time intervals at different temperatures (16 hours at $37{ }^{\circ} \mathrm{C}$ and 2 hours at $50{ }^{\circ} \mathrm{C}$ ), non-enzymatic alkaline hydrolysis by potassium hydroxide, and combined (tandem) hydrolysis (enzyme followed by alkaline). While both conditions of enzymatic hydrolysis yielded similar results, with a slightly higher detected concentration of THC$\mathrm{COOH}$ at $50{ }^{\circ} \mathrm{C}$ during 2 hours compared to enzymatic hydrolysis at $37^{\circ} \mathrm{C}$ during 16 hours, potassium hydroxide hydrolysis exhibited the highest THC-COOH concentrations with extremely low THC-OH and THC values, suggesting that potassium hydroxide does not hydrolyse the ether bond in THC and THC-OH glucuronides, but only the ester bond in the THC-COOH glucuronide $(8,15)$. Enzymatic hydrolysis is more suitable for splitting the ether bond (15). Combined hydrolysis was shown to be the most effective, after which the highest concentrations for all of the analytes were detected, with special emphasis on the THC-COOH concentration, which was higher in comparison with individual hydrolyses. Therefore, tandem hydrolysis, using the enzyme from E. coli at $50{ }^{\circ} \mathrm{C}$ during 2 hours, followed by alkaline hydrolysis at $60{ }^{\circ} \mathrm{C}$ during $15 \mathrm{~min}$, proved to

Table 1 The precision, accuracy, and limit of detection in determining the mass concentrations of cannabinoids and metabolites in rat urine $(\mathrm{N}=6)$

\begin{tabular}{|c|c|c|c|c|}
\hline Analyte & $\gamma(\mu \mathrm{g} / \mathrm{L})$ & Precision (RSD \%) & Accuracy (\%) & Limit of detection $(\mu \mathrm{g} / \mathrm{L})$ \\
\hline \multirow{2}{*}{ THC } & 10 & 4.4 & 96.7 & \multirow{2}{*}{0.9} \\
\hline & 40 & 3.9 & 97.7 & \\
\hline \multirow{2}{*}{ THC-OH } & 10 & 5.9 & 97.6 & \multirow{2}{*}{1.0} \\
\hline & 40 & 4.8 & 99.1 & \\
\hline \multirow{2}{*}{ THC-COOH } & 10 & 5.2 & 97.3 & \multirow{2}{*}{0.8} \\
\hline & 40 & 4.4 & 98.2 & \\
\hline
\end{tabular}

$\mathrm{N}=$ number of replicates at each concentration level; $\gamma$ - mass concentration; RSD - relative standard deviation 
Table 2 Mass concentrations of cannabinoids and metabolites in 24-hour rat urine from the THC and IRI+THC groups

\begin{tabular}{|c|c|c|}
\hline \multirow{2}{*}{ Analyte } & \multicolumn{2}{|c|}{$\begin{array}{c}\text { Mass concentration }(\mu \mathrm{g} / \mathrm{L}) \\
\text { Median (range) }\end{array}$} \\
\hline & THC group $(\mathrm{N}=5)$ & IRI+THC group $(N=5)$ \\
\hline $\mathrm{THC}$ & ND & ND \\
\hline THC-OH & $0.5(\mathrm{ND}-8.5)$ & 1.7 (ND-9.3) \\
\hline THC-COOH & $16.6(15.1-18.4)$ & $18.7 *(18.5-22)$ \\
\hline
\end{tabular}

be the best with the highest detected concentrations of all the analytes.

During hydrolysis, for purposes of urine sample preparation, the effect of a volume of phosphate buffer $(3$ and $6 \mathrm{~mL}$ ) added before hydrolysis to dilute the thick rat urine samples was examined. We concluded that greater dilution is more favourable for further analyses of samples on SPE columns, which resulted in lower chromatogram baseline noise and a larger surface of target peaks. The efficiency of extraction was also increased by sample centrifugation, which removes the tiny particles that originate from the enzymes and significantly endanger the quality of the chromatogram. Hydrolysis was also efficient with the smaller enzyme quantity $(5000 \mathrm{U} / \mathrm{mL})$ and our results were in accordance with the available literature (15).

GC-MS analysis of cannabinoids and metabolites in urine using optimised conditions of hydrolysis and extraction enabled an effective separation of all of the tested analytes. The sensitivity ( $\mathrm{LOD}=0.8-1.0 \mu \mathrm{g} / \mathrm{L}$ ), accuracy $(>96 \%)$, and precision ( $\mathrm{RSD}<6 \%$ ) of the optimised and validated GC-MS method were similar to the values of these parameters obtained by other authors using GC-MS (8) and LC-MS $(12,13)$ for the determination of cannabinoids and metabolites in human urine.

The proposed GC-MS method was used to analyse 24hour urine samples of rats administered only THC and THC in combination with IRI. Enhanced urinary THC-OH and $\mathrm{THC}-\mathrm{COOH}$ concentrations were noted in rats administered combined treatment compared to single THC treatment. Possible explanations for such a result could be the potential redistribution of THC from fatty tissues into blood due to interaction with IRI (7), fatty tissue loss caused by IRI application, which also increases the free fraction of THC in blood available for metabolising (24), or the competition of THC and IRI for the same enzyme in phase II metabolism (conjugation with glucuronic acid mediated by UGT1A1) $(25,26)$.

\section{CONCLUSION}

To understand changes in THC metabolism as a consequence of its concomitant use with different chemotherapeutics, it was necessary to find a suitable method for quantifying $\mathrm{THC}$ and its metabolites in biological samples. The GC-MS method proposed within this study is sensitive, accurate, and precise and therefore acceptable for the quantification of THC metabolites in rat urine.

However, further studies are needed to elucidate the increase of the THC metabolites urinary concentrations in the concomitant use of IRI and THC.

\section{Acknowledgements}

The authors wish to thank Mr. Makso Herman for language editing.

\section{Conflicts of interest}

The authors declare no conflict of interest.

\section{REFERENCES}

1. MacCallum C, Russo E. Practical considerations in medical cannabis administration and dosing. Eur J Intern Med 2018;49:12-9. doi: 10.1016/j.ejim.2018.01.004

2. Lucić Vrdoljak A, Fuchs N, Mikolić A, Žunec S, Brčić Karačonji I, Jurič A, Prester L, Micek V, Neuberg M, Čanović S, Mršić G, Kopjar N. Irinotecan and $\Delta^{9}$-tetrahydrocannabinol interactions in rat liver: a preliminary evaluation using biochemical and genotoxicity markers. Molecules 2018;23:1332. doi: 10.3390/molecules23061332

3. Atakan Z. Cannabis, a complex plant: Different compounds and different effects on individuals. Ther Adv Psychopharmacol 2012;2:241-54. doi: 10.1177/2045125312457586

4. Lowe RH, Abraham TT, Darwin WD, Herning R, Cadet JL, Huestis MA. Extended urinary $\Delta 9$-tetrahydrocannabinol excretion in chronic cannabis users precludes use as a biomarker of new drug exposure. Drug Alcohol Depend 2009;105:24-32. doi: 10.1016/j.drugalcdep.2009.05.027

5. Đorđević S, Krstić N, Kilibarda V, Šulić K, Jovanović B. Prikaz metoda za dokazivanje i određivanje kanabinoida u biološkom materijalu [A review of methods for determination of cannabinoids in biological samples, in Serbian]. Med Rev 2011;3:063-8.

6. Musshoff F, Madea B. Review of biologic matrices (urine, blood, hair) as indicators of recent or ongoing cannabis use. Ther Drug Monit 2006;28:155-63. doi: 10.1097/01. ftd.0000197091.07807.22

7. Grotenhermen F. Clinical pharmacokinetics of cannabinoids. J Cannabis Ther 2003;3:3-51. doi: 10.1300/J175v03n01_02

8. Abraham TT, Lowe RH, Pirnay SO, Darwin WD, Huestis MA. Simultaneous GC-EI-MS determination of $\Delta 9$ tetrahydrocannabinol, 11-hydroxy- $\Delta$ 9-tetrahydrocannabinol, and 11-nor-9-carboxy- $\Delta 9$-tetrahydrocannabinol in human urine following tandem enzyme-alkaline hydrolysis. J Anal Toxicol 2007;31:477-85. doi: 10.1093/jat/31.8.477

9. Brenneisen R, Meyer P, Chtioui H, Saugy M, Kamber M. Plasma and urine profiles of $\Delta^{9}$-tetrahydrocannabinol and its metabolites 11-hydroxy- $\Delta^{9}$-tetrahydrocannabinol and 11-nor- 
9-carboxy- $\Delta^{9}$-tetrahydrocannabinol after cannabis smoking by male volunteers to estimate recent consumption by athletes. Anal Bioanal Chem 2010;396:2493-502. doi: 10.1007/s00216009-3431-3

10. Weinmann W, Vogt S, Goerke R, Muller C, Bromberger A. Simultaneous determination of THC-COOH and THC-COOHglucuronide in urine samples by LC/MS/MS. Forensic Sci Int 2000;113:381-7. doi: 10.1016/S0379-0738(00)00210-3

11. Felli M, Martello S, Chiarotti M. LC-MS-MS method for simultaneous determination of $\mathrm{THCCOOH}$ and $\mathrm{THCCOOH}-$ glucuronide in urine: Application to workplace confirmation tests. Forensic Sci Int 2011;204:67-73. doi: 10.1016/j. forsciint.2010.05.004

12. Schaefer N, Kettner M, Laschke MW, Schlote J, Peters B, Bregel D, Menger MD, Maurer HH, Ewald AH, Schmidt PH. Simultaneous LC-MS/MS determination of JWH-210, RCS-4, $\Delta(9)$-tetrahydrocannabinol, and their main metabolites in pig and human serum, whole blood, and urine for comparing pharmacokinetic data. Anal Bioanal Chem 2015;407:3775-86. doi: 10.1007/s00216-015-8605-6

13. Teixeira H, Verstraete A, Proença P, Corte-Real F, Monsanto P, Vieira DN. Validated method for the simultaneous determination of $\Delta^{9}$-THC and $\Delta^{9}$-THC-COOH in oral fluid, urine and whole blood using solid-phase extraction and liquid chromatography-mass spectrometry with electrospray ionization. Forensic Sci Int 2007;170:148-55. doi: 10.1016/j. forsciint.2007.03.026

14. Battista N, Sergi M, Montesano C, Napoletano S, Compagnone $\mathrm{D}$, Maccarrone M. Analytical approaches for the determination of phytocannabinoids and endocannabinoids in human matrices. Drug Test Anal 2014;6:7-16. doi: 10.1002/dta.1574

15. Kemp PM, Abukhalaf IK, Manno JE, Manno BR, Alford DD, McWilliams ME, Nixon FE, Fitzgerald MJ, Reeves RR, Wood MJ. Cannabinoids in humans. II. The influence of three methods of hydrolysis on the conentration of THC and two metabolites in urine. J Anal Toxicol 1995;19:292-8. doi: 10.1093/jat/19.5.292

16. Bansal T, Mishra G, Jaggi M, Khar RK, Talegaonkar S. Effect of P-glycoprotein inhibitor, verapamil, on oral bioavailability and pharmacokinetics of irinotecan in rats. Eur J Pharm Sci 2009;36:580-90. doi:10.1016/j.ejps.2008.12.005.

17. Böhmdorfer M, Maier-Salamon A, Riha J, Brenner S, Höferl $\mathrm{M}$, Jäger $\mathrm{W}$. Interplay of drug metabolizing enzymes with cellular transporters. Wien Med Wochenschr 2014;164:461-71. doi: 10.1007/s10354-014-0301-1

18. Horikawa M, Kato Y, Sugiyama Y. Reduced gastrointestinal toxicity following inhibition of the biliary excretion of irinotecan and its metabolites by probenecid in rats. Pharm Res 2002;19:1345-53. doi: 10.1023/A:1020358910490

19. Li C, Li X, Choi J. Enhanced bioavailability of etoposide after oral or intravenous administration of etoposide with kaempferol in rats. Arch Pharm Res 2009;32:133-8. doi: 10.1007/s12272-009-1127-z

20. Yamamoto M, Kurita A, Asahara T, Takakura A, Katono K, Iwasaki M, Ryuge S, Wada M, Onoda S, Yanaihara T, Yokoba M, Mitsufuji H, Nishii Y, Fukui T, Masuda N. Metabolism of irinotecan and its active metabolite $\mathrm{SN}-38$ by intestinal microflora in rats. Oncol Rep 2008;20:727-30. doi: 10.3892/ or 00000066

21. Karačić V, Skender Lj. Analysis of drugs of abuse in urine by gas chromatography/mass spectrometry: Experience and application. Arh Hig Rada Toksikol 2000;51:389-400. PMID: 11276966

22. Jung J, Meyer MR, Maurer HH, Neusüß C, Weinmann W, Auwärter V. Studies on the metabolism of the $\Delta 9$ tetrahydrocannabinol precursor $\Delta 9$-tetrahydrocannabinolic acid $\mathrm{A}(\triangle 9$-THCA-A) in rat using LC-MS/MS, LC-QTOFMS and GC-MS techniques. J Mass Spectrom 2007;44:1423-33. doi: $10.1002 / \mathrm{jms} .1624$

23. Martignoni M, Groothuis GMM, de Kanter R. Species differences between mouse, rat, dog, monkey and human CYP-mediated drug metabolism, inhibition and induction. Expert Opin Drug Metab Toxicol 2006;2:875-94. doi: 10.1517/17425255.2.6.875

24. Coskun ZM, Bolkent S. Evaluation of $\Delta^{9}$-tetrahydrocannabinol metabolites and oxidative stress in type 2 diabetic rats. Iran $\mathrm{J}$ Basic Med Sci 2016;19:154-8. PMCID: PMC4818362

25. Santos A, Zanetta S, Cresteil T, Deroussent A, Pein F, Raymond E, Vernillet L, Risse ML, Boige V, Gouyette A, Vassal G. Metabolism of irinotecan (CPT-11) by CYP3A4 and CYP3A5 in humans. Clin Cancer Res 2000;6:2012-20. PMID: 10815927

26. Mazur A, Lichti CF, Prather PL, Zielinska AK, Bratton SM, Gallus-Zawada A, Finel M, Miller GP, Radomińska-Pandya A, Moran JH. Characterization of human hepatic and extrahepatic UDP-glucuronosyltransferase enzymes involved in the metabolism of classic cannabinoids. Drug Metab Dispos 2009:37:1496-504. doi: 10.1124/dmd.109.026898

\section{Optimizacija metode plinske kromatografije-spektrometrije masa za istovremeno određivanje tetrahidrokanabinola i njegovih metabolita u urinu štakora}

S ciljem procjene učinka irinotekana (IRI) na eliminaciju delta-9-tetrahidrokanabinola (THC) mokraćom u eksperimentalnom modelu štakora, razvili smo analitičku metodu za određivanje masene koncentracije THC-a i njegovih metabolita [11-hidroksi-delta-9-tetrahidrokanabinola (THC-OH) i 11-nor-9-karboksi-delta-9-tetrahidrokanabinola (THC-COOH)] u mokraći štakora tretiranih samo THC-om i tretiranih istodobno s THC-om i IRI-jem. U tu svrhu optimizirani su uvjeti hidrolize i ekstrakcije na čvrstom nosaču za ispitivane analite i razvijena je metoda plinske kromatografije-spektrometrije masa (GC-MS) kako bi se kvantificirala sva tri analita u mokraći štakora. Najučinkovitija metoda hidrolize za konjugate THC, THC-OH i THC-COOH bila je tandemska hidroliza enzimom $\beta$-glukuronidazom iz Escherichia coli na $50^{\circ} \mathrm{C} \mathrm{u}$ trajanju od 2 sata koju je slijedila alkalna hidroliza. Predložena metoda je primijenjena za određivanje masene koncentracije analita u 24-satnom urinu štakora. THC nije detektiran ni u jednom uzorku, THC-OH je kvantificiran u $50 \%$ uzoraka, a THC-COOH u svim uzorcima. Uočeno je povećano izlučivanje THC-COOH u mokraći štakora koji su tretirani kombinacijom THC-a i IRI-ja u usporedbi sa štakorima tretiranim samo THC-om. Opisana metoda bila je pogodna za određivanje masene koncentracije metabolita THC-a u mokraći štakora zbog njene osjetljivosti (granice detekcije: 0,8-1,0 $\mu \mathrm{g} / \mathrm{L})$, točnosti $(>96 \%)$ i preciznosti $(\mathrm{RSD}<6 \%)$. 